\title{
Complex congenital scoliosis: brace treatment. What can we expect?
}

\author{
Houria Kaced", H Belabbassi, A Medhkour \\ From 7th International Conference on Conservative Management of Spinal Deformities \\ Montreal, Canada. 20-22 May 2010
}

\section{Background}

Complex Congenital Scoliosis (CCS) is the most frequent cause of non-idiopathic Scoliosis. CCS is a frequent condition in Algeria, and is associated with severe spinal deformities due to failures of formation and segmentation. To date, there is no single treatment that can correct all the deformities in CCS, and the value of Brace Treatment (BT) is still debated. We report our experience in the use of BT in CCS.

\section{Material and methods}

We reviewed files of all patients with CCS that were followed between 2004 and 2009. Patients who had a combination of at least 2 vertebral anomalies, received BT prior and/or following operative treatment and followed for at least one year were included in the study. A basis brace along with deformity specific adaptations was used.

\section{Results}

A total of 25 patients received BT, of which 5 underwent operative fusion of the malformed spinal segment. The mean age was 7.7-year-old, and the sex ratio was 1.5-boy for 1-girl. 8 children had neurological symptoms, and 13 had skin lesions. Imaging studies, which included plain $x$-rays and an MRI of the spine, revealed scoliosis in 15 patients, and kyphoscoliosis in 10. In addition, 6 had syringomyelia, associated with type I Chiari malformation $(\mathrm{n}=2)$, a split cord $(\mathrm{n}=3)$. Isolated diastematomyelia was found in 08 patients, a low fixed cord in 4 , an arachnoid cyst in 3 , and a lipoma in 1 child.

The Milwaukee brace was used in 17 patients and a custom postural brace in 8 . All patients had additional

University Medical Center of Douera, Alger, Algeria

Full list of author information is available at the end of the article adapted devices to correct vicious postures, compensatory curvatures or to allow growth in an aligned posture.

\section{Conclusion}

BT can be effective when the asymmetrical growth potential is not important, and in compensatory curves without vertebral malformations. Cobb angle is not influenced by $\mathrm{BT}$ in rigid and short curves. In our experience, BT is used in an attempt to preserve or correct the global balance of the trunk, while the patient is awaiting surgery, and always customized to each child.

Published: 10 September 2010

doi:10.1186/1748-7161-5-S1-070

Cite this article as: Kaced et al:: Complex congenital scoliosis: brace treatment. What can we expect? Scoliosis 2010 5(Suppl 1):O70.
Submit your next manuscript to BioMed Central and take full advantage of:

- Convenient online submission

- Thorough peer review

- No space constraints or color figure charges

- Immediate publication on acceptance

- Inclusion in PubMed, CAS, Scopus and Google Scholar

- Research which is freely available for redistribution

Submit your manuscript at www.biomedcentral.com/submit
C Biomed Central 